\title{
Interstate Water Compacts: Partnerships for Transboundary Water Resource Management
}

\author{
Cindy G. Roper
}

AUTHOR: Doctoral Student, Strom Thurmond Institute, Clemson University, Clemson, SC, 29634, USA.

\begin{abstract}
While there are both successes and challenges related to the use of interstate water compacts, in their most effective forms they allow states to take a comprehensive, holistic approach to water management. Successful compacts tend to encompass the natural hydrologic boundaries of the water basin. They are more likely to utilize a commission type governance structure with sufficient authority to carry out the mission and goals of the compacting agreement. Successful compacts are flexible and allow for future developments (including climate change) while being cognizant of the need to protect and enhance the environment. They are also sensitive to the needs and desires of various stakeholders, including federal, state, and local governments as well as non-governmental organizations.

Water compacts also face a variety of challenges. They must answer to a wide and diverse constituent base, often with conflicting interests. Stronger states can and do attempt to "bully" other states, severely limiting or eliminating altogether the usefulness of the compact. Governance structures that fail to integrate the interests of all states into a single body simply make the compact into an arena where small scale water wars can be fought.

To illustrate an area where interstate water compacts could make a significant contribution, this paper concludes with a case study highlighting South Carolina's transboundary water issues with North Carolina and Georgia. Recommendations for South Carolina include beginning negotiations toward the development of federal-interstate compacts as well as considering action in the Supreme Court in the event that these negotiations fail.
\end{abstract}

\section{INTRODUCTION}

Of the fifty states that comprise the United States of America, only two - Alaska and Hawaii - do not share a ground or surface water resource with another state. Accordingly...the forty-eight contiguous states fall into one of two categories: those states that are (or have been) involved in an interstate water conflict or those states that are going to be involved in an interstate water conflict (Sherk, 2005, p.765).
That statement was made nearly ten years ago. Since then, increasing population, climate change and new technologies are putting even more pressure on water resources. States are having to re-evaluate how they manage these assets, both within their borders and those that are shared with neighboring states. As part of this process, state officials need to develop a clear picture of what future needs and conflicts may emerge and how these might be mitigated. They also need to prepare flexible mechanisms for dealing with the uncertainty that accompanies almost any planning effort. Without the means to successfully address transboundary water issues, options are limited and too often result in undesirable outcomes.

The purpose of this paper is to examine federalinterstate compacts as a possible solution to both existing and emerging issues related to shared water resources. It provides an overview of the advantages and challenges of utilizing interstate compacts as well as giving examples of compacts that have experienced various rates of success. Furthermore, it examines transboundary water issues and the prospect of compact development in South Carolina.

The information in this paper is especially relevant for those who are charged with providing solutions to problems emerging from shared water resources. It provides an alternative to piecemeal administration that is not equipped to deal with problems that require the broad participation of other parties to solve. Overall, this paper illustrates a mechanism that allows for extensive stakeholder participation within a comprehensive, flexible framework that has been shown to work in complex transboundary water resource situations.

\section{METHODOLOGY}

This paper is a comparative study of factors that likely influence the success or failure of interstate water compacts. It utilizes scholarly writings, legal and historical sources, governmental and non-governmental reports, and media sources. It also relies substantively on the work of the Utton Transboundary Resource Center at the University of New Mexico School of Law as a guide to compact development and function. It concludes with a case study that uses the 
findings from the research to provide an example of the possible utilization of interstate compacts for water resource management in South Carolina.

\section{BACKGROUND AND RELATED WORK}

Under federalism, states have primary responsibility for water within their borders while the federal government regulates and manages water resources under the Commerce Clause, the Federal Clean Water Act, the Endangered Species Act, the Rivers and Harbors Act and in conjunction with the Army Corps of Engineers. The federal government also constructs and controls large-scale reclamation and flood control projects and licenses non-federal hydropower projects through the Federal Energy Regulatory Commission (Muys, 1995). This jumble of responsibilities often leads to ambiguity as to what federal or state entity has jurisdiction over a specific body of water or section of river, ultimately resulting in some degree of conflict (Mandarano, Featherstone, and Paulsen, 2008). Lepawsky stated the problem rather succinctly when he said, "Few functions of the American Federal system seem less suited physically to state boundaries than the management of our water resources" (1950, p. 631). Mandarano, Featherstone, and Paulsen comment in more detail.

Water and federalism are a complicated mix as water flows through the hydrologic cycle without regard to political boundaries. The physical boundaries of river basins do not coincide with the geographic boundaries of political jurisdictions. The management of interstate water resources is complicated by the multiple, conflicting, and overlapping functions and interests of federal and state governments, and is further complicated by conflicting regulatory authority and policy priorities between different federal agencies (2008, p. 136).

Compacts, as problem-solving mechanisms, date back to the pre-revolutionary period. Their origins emerged, for the most part, from early boundary disputes that were settled by negotiated agreements between the colonies and were contingent upon the approval of the Crown (Kearney and Stucker, 1985). Later, in the Articles of the Confederation, compacts reflected the need to settle disputes among states as well as to protect the new nation "from the destructive political combination of two or more States" (Frankfurter and Landis, 1925, p. 693). In the same vein, Article 1, §10, Clause 3 of the U.S. Constitution forbids states to enter into agreements among themselves without the approval of Congress (U.S. Constitution, Article I., n.d.), reinforcing the importance of compacts as tools for protecting the union as well as solving problems between states.

The Supreme Court has made itself clear on the issue of intervening between states. In Colorado v. Kansas, the Court explained why adjudication was not the most efficient way to solve interstate water disputes.

The reason for judicial caution in adjudicating the relative rights of States in such cases is that, while we have jurisdiction of such disputes... they involve the interests of quasi-sovereigns, present complicated and delicate questions, and, due to the possibility of future change of conditions, necessitate expert administration rather than judicial imposition of a hard and fast rule. Such controversies may appropriately be composed by negotiation and agreement, pursuant to the compact clause [emphasis added] of the federal Constitution. We say of this case, as the court has said of interstate differences of like nature, that such mutual accommodation and agreement should, if possible, be the medium of settlement, instead of invocation of our adjudicatory power (1943, 320 U.S. 383).

Furthermore, in Nebraska v. Wyoming, the Court reiterated that in undertaking the apportionment of an interstate river, they would "embark upon an enterprise involving administrative functions beyond our province" (1945, 325 U.S. 616). Clearly, the Court believes that compacts are a viable tool for managing water resources that cross state lines and should be utilized whenever possible.

As such, interstate compacts can serve as a platform for intergovernmental cooperation. They allow states to exercise authority over issues within their purview while relieving the federal government of responsibility for problems better left to the states. At the same time, they provide a method for states and the federal government to work together to "solve mutual problems in a collective fashion" (Kearney and Stucker, 1985, p. 210).

Basically, the compact is a legal agreement between two or more states entered into in order to deal with a problem or concern that crosses state boundaries. Because of its contractual nature, a compact takes precedence over prior law and over legislation that may later be enacted by member states. Because a compact is also a contract between the participating states, it differs from other statutes. As a contract, an interstate compact is binding on member states in the same manner as any other contract entered into by an individual or corporation. Once entered into, compacts cannot be unilaterally amended or repealed; they are binding on all citizens of the signatory states. If a state violates or fails to honor the terms of a compact, an offended state or states may sue in state or federal court (Florestano, 1994, p. 14). 
Compacts can be relatively simple or they can be comprehensive documents that can consist of nearly unlimited combinations of goals, purposes, and organizational structures (Frankfurter and Landis, 1925). In general, compacts provide a principal means by which states can allocate water from common river systems, they help provide for efficient use and equitable apportionment of shared resources, and they serve to administer rules and develop strategies to insure compliance (Schlager and Heikkila, 2009). Compacts have changed over time and vary according to scope. Among the early compacts, the chief water officials for the participating states were responsible for gathering hydrologic data on water supplies and usage and issuing regulations to carry out the apportionment plan (Muys, 1995). Later and more comprehensive compacts such as the Delaware River Basin Compact cover issues of water supply, pollution control, flood protection, watershed management (soil conservation, forestry, and fish and wildlife), recreation, hydropower, and regulate water withdrawals and diversions (See Ankersen and Hamann, 1996, p. 506).

Two major types of interstate compacts have emerged from the range of possibilities for organizational structures. The first is a compact between states, ratified by the states' legislatures and by Congress but without the federal government as an active participant. In the second type, the federal-interstate compact, the federal government is an active member of the compact, often with voting rights (Muys, 1995; Zimmerman, 2012). Federal-interstate compacts address two major goals for regional water resource planning and management; first, providing a regional viewpoint to guide the development and implementation of comprehensive water resource planning and, second and perhaps more importantly, realizing meaningful coordination of federal, state, and private resource planning and activities (Muys, 1995). There are currently seven federalinterstate compacts; four of which deal with transboundary water resource issues (Zimmerman, 2012).

\section{SUCCESSFUL INTERSTATE COMPACTS}

Successful interstate water compacts tend to share certain characteristics. Viable compacts must be able to meet and negotiate changing conditions, therefore, they must be designed with flexibility in mind. Successful compacts are often those specifically created for individual circumstances. Also, successful compacts are those that can be implemented with few external constraints. Another characteristic of successful compacts is that they routinely involve water resource management experts who have a better understanding of technical data, long-term outcomes, and different available options (Tarlock, cited in Stephenson, 2000). George Sherk (2005) provides a list of institutional attributes that he argues can contribute to creating effective compacts. Many of these have been incorporated into the model compact developed by the Utton Transboundary Resources Center in the University of New Mexico's School of Law (Muys, Sherk, and O'Leary, 2007) of which he is a co-author.
The first factor recommended for successful interstate water compacts is clearly defined boundaries. These boundaries delineate both geographic borders (Muys et al., 2007) as well as who may access the resources (See Ostrom, 1990). For successful water compacts, a river basin, including its hydrologically connected subsurface waters, is considered the optimal geographic boundary (Muys et al., 2007). This is a critical aspect of compact development because when using political boundaries, excellent management in one state can be nullified by poor management in adjacent states sharing the same river basin (Dellapenna, 2006). That being the case, interstate management within the hydrological boundaries of a river basin is substantially more likely to succeed than management utilizing political boundaries. Defining who may access the resources helps to avoid overuse and resource depletion (See Hardin, 1968; Ostrom, 1990) and is critical for basin management.

A successful compact requires that allocation and provision rules and local conditions be internally consistent (See Ostrom, 1990). Too many water compacts have been based on over-allocation from the beginning, generating conflict and contributing to compact failure (Muys, 1995). Instead, within each river basin, a "safe yield" should be determined (Sherk, 2005) and water apportioned to ensure that adequate stream flows are maintained in each state (Muys et al., 2007). Monitoring is another element of successful water compacts (Muys et al., 2007; Ostrom, 1990). In the model compact, disputes are resolved either by agreement or administrative determination with states having primary responsibility for enforcement of rules and allocations (Muys et al., 2007; Sherk, 2005). Violations are treated in ways that encourage "candor, cooperation, and compliance" (Muys et al., 2007, p. 93). If these fail, then the parties may initiate litigation (Muys et al., 2007).

\section{The Importance of Compact Commissions}

Because compact commissions are such an essential part of many successful compacts they warrant special attention. Compact commissions are, as Stephenson says, "...how interstate water compacts make their greatest contribution to water resource management" (2000, p. 99). These permanent commissions provide authority and structure for the agreements (Stephenson, 2000), gather information, meet and discuss water problems, develop regulations to administer compacts, monitor water use, and mediate conflict (Schlager and Heikkila, 2009). Compact commissions also allow for the participation of stakeholders in decision making and for transparency in processes and outcomes (See the Delaware River Basin Compact, 1961).

According to the Utton model compact, commission members include the governors of all of the signatory states or their representatives, a single tribal representative elected from all tribes who are parties to water allocation agreements within the jurisdiction of the compact, and a federal representative. This federal representative is appointed by the President after consultation with federal agencies with interests in the basin and he or she will actively participate in 
the commission's discussions. The federal representative will coordinate the viewpoints of all federal agencies in the basin with responsibilities related to water resources and present a single, coordinated federal position during commission deliberations (Muys et al., 2007).

Some of the powers that are critical to a strong commission include the ability to carry out comprehensive planning, making and enforcing rules, monitoring compliance, financing and constructing projects, and approving intra- and inter-basin transfers. Commissions are also empowered to acquire, hold, convey and dispose of property, enter into contracts, sue and be sued, issue permits, collect fees, levy taxes, and establish standards. They can also negotiate for loans, grants, and services and perform all functions required by the compact. Other aspects of successful commission functioning include majority voting rules with a tie-breaker provision, allowing the federal member a vote, having power to act in an emergency, and other necessary and proper ancillary powers (Muys et al., 2007).

\section{The Delaware River Basin Compact}

The Delaware River Basin Compact (DRBC), the first federal-interstate compact developed, has emerged as a model compact (Dellapenna, 2006; Muys, 1995; Zimmerman, 2012). However, its beginnings were anything but ideal. New Jersey, New York and Pennsylvania began negotiations regarding a possible interstate compact as early as 1923. In 1926, New York City, in a predatory move toward Delaware, announced that it planned to utilize the river as a major municipal water source - even though the city has no remotely riparian claims on the river. This initiated an extended confrontation between New York, an upper basin state, and the lower-basin states of New Jersey and Pennsylvania. New Jersey sued in the Supreme Court which applied the doctrine of equitable apportionment with New York receiving about two thirds of what New York City had originally requested. This was later increased but not surprisingly, none of the states were satisfied with the Supreme Court ruling (Dellapenna, 2005).

The equitable apportionment ruling did not create a comprehensive integrated basin management system nor could the Court return to the allocation plan every time a new issue emerged. As a result, in 1936, the three states created the Interstate Commission on the Delaware River Basin (INCODEL). This commission was developed without Congressional approval, indicating that neither the states nor the federal government considered this agency a major player in the basin. After the INCODEL failed, Delaware joined the other three states in the basin in proposing the Delaware River Basin Commission Compact. Adopted by the states in 1949, it went into effect with congressional ratification in 1952. This compact also failed. The Commission lacked the powers needed to carry out the goals and objectives of the compact. Specifically, the Commission had no authority to regulate water usage even though different uses might interfere significantly with the plans of the agency. Shortly after that compact went into effect, the states began negotiations for the second compact, the current Delaware River Basin Compact (DRBC) (Dellapenna, 2005).
The current compact was approved by Congress in 1961. In addition to the inclusion of the federal government as a full partner, a major strength of this compact is that it is administered by a commission with broad powers to carry out its responsibilities. These powers include the critical ability to borrow money and issue bonds, giving the commission the wherewithal to maintain a necessary amount of independence. Other successful aspects of the DRBC include the ability to aid in the coordination and integration of federal, state, municipal, and private agencies and the development of a comprehensive plan addressing both immediate and long range water resource needs (Delaware River Basin Compact, 1961; Muys, 1995). In addition, the DRBC also recognizes the overarching importance of allocating water equitably, without regard for artificially imposed borders; “...to apply the principle of equal and uniform treatment to all water users who are similarly situated and to all users of related facilities, without regard to established political boundaries" [emphasis added] (Delaware River Basin Compact, 1961, Article 1, § 1.3, ๆ (e)).

This new compact resulted in a commission that was a regulatory agency in addition to its planning and operational functions. The new commission also has extensive authority for hydropower development, pollution regulation, watershed management, and the development of flood protection and recreational facilities in addition to its former mandate to provide public water supplies (Delaware River Basin Compact, 1961; Dellapenna, 2005).

Most importantly, for states concerned with issues of autonomy and sovereignty, it should be noted that in two important ways, the DRBC's regulatory system is more limited than those of the states in the basin. First, water withdrawal permits are only needed in "protected areas" where water demand results in a shortage or interferes with the Commission's comprehensive plan. These permits can be reviewed in any court with competent jurisdiction. Second, the authority to issue withdrawal or diversion permits rests with those states with an effective water use permitting system. In a water emergency, however, state permits may be superseded (Delaware River Basin Compact, 1961; Dellapenna, 2005). Although a number of suits have been brought against it, the success of the DRBC was such that, in 1970, it became the template for the Susquehanna River Basin Compact (SRBC) (Dellapenna, 2006).

\section{COMPACTING CHALLENGES}

Compacts can and do fail. There are a variety of barriers to developing and implementing successful interstate water compacts. There are often diverse cultural, political, historic and economic priorities that each group brings to the negotiations. Parties to these types of agreements must often cooperate and collaborate with others of widely divergent interests (Mulroy, 2008).

Developing and implementing an interstate compact can be a complicated, expensive, and time consuming project 
(Burke, 2004; Meyers citied in Stephenson, 2000). Because of often substantial federal interests in the areas covered by compacts, these agreements must also account for the participation of these and other stakeholders (Mandarano et al., 2008; Sherk, 2005). In some cases, state elections, especially those for governor, may temporarily interrupt the administration of a compact given the relationship between that office and a compact commission. Ambiguous language and unresolved issues can also plague a compact (Burke, 2004) while a lack of accurate data and faulty or no planning for future development can threaten to derail elements of it years down the road (McClurg, 1997).

A major issue in compact development is that states are often reluctant to delegate significant authority to a regional commission or other authority that they realize may not always act in their best interest. Muys (1995) points out that states should take into consideration that as they are more able to restrain compact agencies to protect their sovereignty, they are also increasing the likelihood that regional water issues will escalate to the point that they will come under federal jurisdiction, overriding state or local authority.

\section{The ACT and ACF Compacts}

The Alabama-Coosa-Tallapoosa (ACT) and the Apalachicola-Chattahoochee-Flint (ACF) compacts are examples of failed efforts to find a solution to a growing water crisis. Conflicts over water between Georgia, Alabama, and Florida (the ACF) and between Georgia and Alabama (the ACT) had resulted in a prolonged attempt to develop and implement an interstate water compact. Although deadlines for compact development were extended several times, the states were unable to reach a compromise and no effective compact has emerged (Dellapenna, 2006). This failure can be attributed to several problems associated with water compacts.

Primarily, the states relentlessly protected their own interests and failed to negotiate in good faith (Mandarano et al., 2008; Stephenson, 2000). In addition, these compacts (ACT and $\mathrm{ACF}$ ) lacked many of the attributes that made the DRBC and the SRBC so effective (Dellapenna, 2006). For example, while the DRBC Commission has the power to allocate waters to and among the compact states and to impose conditions, the ACT/ACF Commission was limited to planning, coordinating, monitoring, and making recommendations concerning the water resources of the basin (Delaware River Basin Compact, 1961; Alabama-Coosa-Tallapoosa River Basin compact.1997; Apalachicola-ChattahoocheeFlint River Basin compact.1997). Another problem with the ACF compact centers on the treatment of federal agencies (Dellapenna, 2006). Given the huge federal expenditures in the basin, in excess of $\$ 1.5$ billion just for the Army Corps of Engineers, the proposed compact called only for minimal federal participation, an unacceptable situation for the U.S. Department of Justice (Reno cited in Sherk, 2005).

Some of the problems with the ACT/ACF were not related to compacts per se but are important in the negotiating process. First, there were problems with negotiating in a public forum. Stakeholders representing various organizations were present and were unable to compromise in many cases. Politically, there was fallout for current office holders as no matter what the outcomes, a number of stakeholders were not going to agree. There were also technical issues such as regulating flow versus regulating consumptive uses. Georgia was willing to talk about one but not both. Finally, Georgia negotiated from the position that they needed far more water than the other states (Kerr in Burke, 2004), a position that may have been hard to sell to Alabama and Florida.

\section{The Colorado River Compact}

Not the stunning success of the Delaware River Basin Compact nor the abysmal failure of the ACT/ACF, the 1922 Colorado River Compact continues to be a source of controversy. The primary purposes of the compact included dividing the river flow between the states of the Upper Basin (Colorado, Wyoming, Utah, and New Mexico) and the Lower Basin (Arizona, California, and Nevada), eliminating future disputes, and promoting the orderly development and management of the river (Colorado River Governance Initiative, 2010). However, the number and scope of "agreements, contracts, treaties, laws, and court decisions" (McClurg, 1997, p. 7) that make up "the law of the river" governing the Colorado today, indicate that there was a great deal of ground not covered in the original compact. These topics include environmental issues, increasing development, growing water shortages, water transfers, the rights of Native Americans to water, and a possible dispute with Mexico over water promised by treaty in 1944 .

The Colorado River Compact was finally ratified as part of the Boulder Canyon Project Act of 1928, authorizing the construction of the Hoover Dam and apportioning the water of the lower basin between the states. A 1944 treaty with Mexico further apportioned the river and in 1948, the Upper Colorado River Basin Compact allocated the Upper Basin apportionment by percentages between participating states. Court cases and negotiated settlements delineate tribal rights whose allocations are taken from the state in which the reservation is located. The Law of the River also includes Congressional authorization for a number of water projects such as the Colorado River Storage Project Act in 1958 which provided an Upper Basin Development Plan and construction of the Glen Canyon Dam (Lake Powell). Even with the compact, the Supreme Court has had to step in and specify how much water each state was entitled to (See Arizona v. California, 1963). The Court has revisited the issue numerous times, the last time in 2006 (See Arizona v. California, 2006). In addition, there are also a number of national and regional environmental laws that are part and parcel of the Law of the River (Colorado River Governance Initiative, 2010).

Given that, on average, water demands have exceeded water supplies in the Colorado River Basin over the past decade, there is little doubt that changes will need to be made. In the future, decreased water flow due to even a modest change in climate will be problematic. At high levels of climate change, the lack of water will become disastrous (Colorado River Governance Initiative, 2010; Robison and 
Interstate Water Compacts: Partnerships for Transboundary Water Resource Management

MacDonnell, 2014). In the event of a compact call, "Not only might the Law of the River prove unmanageable, but it may actually collapse under the weight of the situation" (Colorado River Governance Initiative, 2010, p. 18).

\section{Other Challenges}

The American Central Plains and Southwest regions are currently suffering from extremely warm and dry conditions which are expected to continue for decades (Cook, Ault, and Smerdon, 2015). The Rio Grande is now being reduced to "a trickle" due to lack of rain and continued consumption by both metro and agricultural users. Arizona is preparing for future cuts in its allocation from the Colorado River should the water level in Lake Mead continue to fall (Wines, 2015). On April 1st of this year, Governor Jerry Brown of California announced mandatory water restrictions to help address the current drought (Nagourney, 2015).

Some other problem spots for water resource management include the Catawba River between North and South Carolina as well as the Savannah River between South Carolina and Georgia. On the Catawba, it appears that neither state is willing to compact and disputes have already erupted, lessening the chance of a viable compact in the near future (Dyckman, 2008). In each case, critical decisions will have to be made about water resources and one of the best ways to do this will often be through interstate compacts.

\section{SOUTH CAROLINA: A CASE STUDY OF PROSPECTIVE COMPACT DEVELOPMENT}

In addition to providing drinking water, water for industry, irrigation, hydropower, waste assimilation, transportation, and flood control, South Carolina's water ways also provide habitats for fish, wildlife and plant species as well as migration routes critical for species reproduction (Wachob, Park, and Newcome, 2009). Pressure is increasing on these resources due to population growth as well as changes in how water is used. In previous centuries, water use was, for the most part, limited to instream and non-consumptive uses - e.g., transportation, hydro-mechanical power, and fishing. Burgeoning technology, however, has brought new and more consumptive uses. In 2006, thermoelectric power, for example, was second only to hydroelectric power in water use in this state, utilizing some 3.5 trillion gallons of surface water (Holman, 2008).

South Carolina, along with North Carolina and Georgia, is facing a number of critical water resource issues. These include but are not limited to water allocation, water quality, drought management, salt water intrusion, assimilative capacity, stream flow maintenance, ground water usage, and flood control (Catawba-Wateree Basin Advisory Commission. n.d.; Savannah River Basin Advisory Council, n.d.; Wachob et al., 2009). These issues are important in that efforts by one state to address a problem often impacts another state in negative ways. For example, ground water pumping to support development or combat water shortages in one state can lead to salt water intrusion in another (Wachob et al., 2009).

South Carolina has four major river basins, three of which it shares with neighboring states. The two largest, the Yadkin-Pee Dee and the Catawba-Santee (aka the CatawbaWateree) are shared with North Carolina. The Savannah Basin is shared with Georgia with a small, northernmost portion located in North Carolina. The final basin, the Ashepoo-Combahee-Edisto is located entirely within South Carolina (Badr, Wachob, and Gellici, 2004) and is not subject to transboundary issues with another state.

Of the three states - North Carolina, South Carolina, and Georgia - South Carolina is currently the least populated and is growing at the slowest rate. Even so, the state is predicted to gain over a million people between 2000 and 2030. North Carolina and Georgia are both more populous and growing at considerably higher rates (See Table 1). From 2000 to 2030, according to predictions, North Carolina will gain just over 4 million people and Georgia just under 4 million (U.S. Census Bureau, Population Division, 2005). Given the population differences across the states and the needs of these populations for water as well as the desire for South Carolina to grow, a solution will be needed that balances these factors and the water resources equitably.

Even though it has a smaller and slower growing population, South Carolina's water resources are heavily impacted by its faster growing neighbors. During drought conditions, for example, both North Carolina and Georgia increasingly rely on rivers shared with South Carolina. Coastal cities such as Myrtle Beach depend on water supplies from North Carolina and have experienced shortages. These conditions make maintaining stream flow a major challenge and increase the probability of conflict between states sharing these resources (Burke, 2004, p. 296; Holman, 2008; Wachob et al., 2009).

In 2009, South Carolina confronted North Carolina in the U.S. Supreme Court regarding proposed water withdrawals from the Catawba River. Interbasin transfers in North Carolina endanger water quality and flow in the coastal areas of South Carolina (League of Women Voters of South Carolina Water Resources Study Committee, 2011). This can be seen in South Carolina's Yadkin-Pee Dee Basin where the river is impacted by the upstream needs of six reservoirs, all of which are located in North Carolina. At the same time, salt water incursion into the lower Pee-Dee River has resulted in a need for increases in the minimum

Table 1. Population Projections for North Carolina (NC), South Carolina (SC) and Georgia (GA): 2015-2030.

\begin{tabular}{lccccc}
\hline & 2015 & 2020 & 2025 & 2030 & $\begin{array}{c}\text { Change } \\
2000 \text { to 2030 }\end{array}$ \\
\hline NC & $10,010,770$ & $10,709,289$ & $11,449,153$ & $12,227,739$ & $51.9 \%$ \\
SC & $4,642,137$ & $4,822,577$ & $4,989,550$ & $5,148,569$ & $28.3 \%$ \\
GA & $10,230,578$ & $10,843,753$ & $11,438,622$ & $12,017,838$ & $46.8 \%$ \\
\hline \multicolumn{7}{l}{ Note. Adapted from the U.S. Census Bureau, Population Division, Interim State Population Projections }
\end{tabular}

2005 
flow required from North Carolina (Wachob et al., 2009). Meanwhile, in Georgia, Atlanta is seeking potential water sources that include Lake Hartwell (League of Women Voters of South Carolina Water Resources Study Committee, 2011), on the border between South Carolina and Georgia, and part of the Savannah River Basin.

\section{The Savannah River Basin}

The Savannah River begins in North Carolina, forms the boundary between Georgia and South Carolina and empties into the Atlantic at the port of Savannah. The river basin has a number of important issues that will either require cooperative efforts between the states or may escalate into litigation. Among these are water quality issues, drought, economic development and population growth, fish and wildlife concerns, regulatory issues and the Savannah Harbor Expansion Project (Georgia Environmental Protection Division and SC Department of Health and Environmental Control, n.d.; SC Savannah River Basin Advisory Council, n.d.).

In a 2004 report, the South Carolina Governor's Water Law Review Committee (GWLRC) supported a compact with Georgia as a viable method to apportion the resources of the Savannah River Basin. However, while recognizing that both states have an interest in the entire river and that there is a need for consistency between the states in areas such as water quality standards and FERC relicensing (Governor's Water Law Review Committee, 2004), it does not appear that there are any recommendations for a strong, resilient, basin-wide governing body similar to those found in more successful water compacts. In fact, the GWLRC specifically suggests that the compact utilize various protocols that would "obligate each state to manage its basin resources in a consistent manner" (Governor's Water Law Review Committee, 2004, p. 24) but carefully avoids any commitment to common governance. That being said, the GWLRC has highlighted a number of elements that may contribute to the development and ratification of a successful Savannah River Compact.

When discussing the allocation of the usable water, the Committee acknowledges the many stakeholders involved, including the significant role of the Army Corps of Engineers (CoE) and other federal agencies. In case of drought, cooperation and coordination with the $\mathrm{CoE}$ will be essential since they control significant resources on the river. Another positive element from the GWLRC report is the recognition of the importance of accurate data. Unlike the Colorado River Compact, where the river was overallocated from the beginning, having a realistic estimate of the available water supply can only enhance the working of any compact that may emerge.

The GWLRC proposal also advocates addressing the looming issue of interbasin transfers. It specifically notes that while Greenville and Beaufort-Jasper together are permitted to access 210 million gallons per day from the basin, Georgia also has the potential for a very large transfer from the Savannah. Again, inclusion of the CoE, who also oversees a major supplier of water to Atlanta, Lake Lanier, can, at the very least increase the scope, accuracy and reliability of the knowledge available and significantly improve any compacting efforts.

Although the GWLRC acknowledges that various state and federal agencies with interests in the environment conduct activities within the Savannah River Basin, there is no evidence of real concern about the environment itself. The only mention of the Clean Water Act is related to FERC relicensing and there is one mention of endangered species. In reality, the Clean Water Act and the Endangered Species Act will significantly impact the way states will manage the Savannah River resources. The possible consequences of these laws must be incorporated into any viable compact. In addition to support from the GWLRC, the 2004 South Carolina Water Plan (Badr et al.) also calls for the development of a compact between the state and others that share water resources. "Compacts", the authors point out, "will promote interstate coordination, reduce potential disputes between the states, enhance the flow regime of many of South Carolina's rivers and extend the availability of water during severe droughts" (p. vi).

Like its South Carolina counterpart, the Georgia Comprehensive State-wide Water Management Plan (Georgia Environmental Protection Division, 2008) recognizes the need for flexibility, the importance of including various stakeholders, and the need for relevant and accurate data. However, unlike the South Carolina plan, there is no mention of the possibility of a compact or any coordinated effort with South Carolina regarding the Savannah River.

The Savannah River Basin Water Caucus, a joint effort between South Carolina and Georgia, is composed of legislators from counties on both sides of the river. A major purpose of the Caucus is to avoid lengthy and costly litigation between the states as South Carolina threatens action against Georgia over water allocation. While there has been mention of an interstate water compact for the Savannah Basin (Cary, 2013), it is too early in the process to determine if this option will actually reach the Caucus' agenda.

An earlier effort, the Savannah River Basin Partnership between the Georgia Environmental Protection Division and the South Carolina Department of Health and Environmental Control was established by Governor Sanford of South Carolina and Governor Perdue of Georgia in 2005. Major topics for this group included salt water intrusion into the Upper Floridan aquifer, dissolved oxygen standards along with associated Total Daily Maximum Loads (TDML), and sustainable water use in the basin. Currently, the status of shared planning for this group includes the previously mentioned Georgia Comprehensive State-Wide Water Management Plan (Georgia Environmental Protection Division, 2008) and the South Carolina Water Plan (Badr et al., 2004). There's no indication of comprehensive basinwide planning by the two states (Georgia Environmental Protection Division and SC Department of Health and Environmental Control, n.d.). In April of 2012, Governor Haley of South Carolina signed Executive Order 2012-05, 
Interstate Water Compacts: Partnerships for Transboundary Water Resource Management

re-establishing the Governor's Savannah River Committee of South Carolina, initiating another round in the South Carolina/Georgia talks.

\section{The Catawba-Wateree and Yadkin-Pee Dee Basins}

In the face of what will likely become critical water shortages, North and South Carolina have both developed legislation supporting River Basin Advisory Commissions for the Catawba-Wateree and Yadkin-Pee Dee basins (North Carolina General Assembly, n.d.; South Carolina General Assembly, 2004). Very similar to the process for developing a compact, each state adopted legislation that specifies the scope of each commission's work as well as the composition, responsibilities, and powers of the commissions. In fact, there are many similarities between the legislation for these commissions and the Utton Center's model compact (See Muys et al., 2007). A major difference however, is that by law, the commissions are advisory only in nature: There are no provisions for regulatory or other administrative authority.

It is important to note that the Catawba-Wateree River Basin Commission (CWRBAC or the Basin Commission) provides an example of a unified approach to basin management much like those found in the most successful compacts. Briefly, the Basin Commission provided a platform for South Carolina and North Carolina, along with Duke Energy, the Catawba River Water Supply Project, and other stakeholders to negotiate an agreement to resolve South Carolina v. North Carolina without further litigation and expense (See South Carolina v. North Carolina settlement agreement, 2010). The Settlement Agreement reflects the joint nature of the negotiations, especially given the alternative of further litigation -

...by reaching this Agreement the Parties will achieve a better result than could be achieved through the Litigation with a substantial cost savings to the taxpayers and ratepayers in both States. The Parties also believe that it is important that the States regard each other as close neighbors, which share the CatawbaWateree River ("River"), rather than as a plaintiff and a defendant in a lawsuit and that this Agreement will be a model for regional cooperation (2010, p. 1).

In adopting a common approach to managing the resources of the river basin, North Carolina and South Carolina have taken an important first step toward an eventual compact should one be desired.

While the Catawba-Wateree Basin Advisory Commission has been active since its initial development, there is insufficient evidence to indicate that a viable YadkinPee Dee Basin Advisory Commission has emerged. Perhaps the issues that led to South Carolina v. North Carolina acted to spur the creation and maintenance of the Catawba-Wateree Basin Commission whereas the Yadkin-Pee Dee has not yet reached that critical state.

\section{CONCLUSIONS AND RECOMMENDATIONS}

Georgia, South Carolina, and North Carolina are facing water resource management issues that are becoming increasingly common, even east of the 100th meridian. It is critical now that states develop a method or methods for solving their differences that reach beyond their tendency, and that of their agencies, to protect their own interests ahead of those of the basin. By utilizing interstate water compacts with adequate power and resources to carry out comprehensive planning, coordination, and management (Hayton and Utton, 1989), the basin itself, in the form of the commission, becomes a principal actor. Depending on the organizational structure, either state agencies or agencies developed and implemented by the commission itself are responsible for carrying out the mandates of the compact within the basin. Monitoring (See Ostrom, 1990), transparency, and accountability reduce agency costs and promote trust (See Gortner, Nichols, and Ball, 2007) in the commission even as it acts as an agent for the stakeholders in the basin.

Developing a compact can be a long and complex process. The time to start is now. In riparian states, the state with the fastest growth may have an advantage in court cases, especially when the faster growing state has already appropriated water. In these instances, courts may be unwilling to limit existing diversions (Kansas v. Colorado, 1907; Burke, 2004). If it's true, as Burke suggests, that Metro Atlanta's position as the fastest growing area in the region gives Georgia an advantage over Alabama with regard to the Chattahoochee (2004), then Georgia will also have the advantage over South Carolina regarding the Savannah. In addition, if the issues between North Carolina and South Carolina move to litigation in the Yadkin-Pee Dee Basin, South Carolina, because of its slower growth may be at a disadvantage there, too.

South Carolina and North Carolina have shown that they can work together in the Catawba-Wateree Basin. The next move forward is to begin conversations about the possibilities of developing federal-interstate compacts utilizing the components that have been so effective on the Delaware and Susquehanna river systems. As contracts, these compacts can provide protection from both prior and subsequent legislation (Florestano, 1994) and with the federal government as a partner, they can garner cooperation from a major player in water resource management.

Given Georgia's history with Alabama and Florida, South Carolina should immediately exert concentrated and sustained efforts to start negotiations toward the development of a compact with that state. This effort should be made in good faith and with the understanding that each state has the right to an equitable utilization of the water resource as well as a duty to avoid appreciable harm to a co-basin state (See Hayton and Utton, 1989, p. 672). At the same time, South Carolina should also consider taking the initial steps prior to filing an action in the Supreme Court for equitable apportionment. This could provide leverage for South Carolina while encouraging Georgia to negotiate (Holman, 2008). 
Compacts are not the solution for every interstate water problem. However, they do supply a platform that can be tailored to each unique situation and they can also have builtin flexibility to deal with issues that have not yet emerged when legislation is passed enabling the compact. By treating a river basin as a political entity in its own right, a compact can provide local stakeholders control of a resource that impacts so many water users in so many ways.

\section{ACKNOWLEDGEMENTS}

I would like to thank the reviewers for their helpful comments and I would especially like to thank Dr. Jeff Allen, Director of the South Carolina Water Resources Center at the Strom Thurmond Institute for his insights, encouragement, and humor. Thanks also to the journal staff, Dawn Anticole White of Clemson University, for her kindness in keeping things on track.

\section{LITERATURE CITED}

Alabama-Coosa-Tallapoosa River Basin compact, 1997. Retrieved from http://frwebgate.access.gpo.gov/cgi-bin/ getdoc.cgi?dbname=105_cong_billsanddocid=f:hj92enr.txt. pdf

Ankersen, T. T., and Hamann, R., 1996. Ecosystem management and the everglades: A legal and institutional analysis. Journal of Land Use and Environmental Law, 11(2S), 473-536.

Apalachicola-Chattahoochee-Flint River Basin compact, 1997. Retrieved from http://frwebgate.access.gpo.gov/cgi-bin/ getdoc.cgi?dbname $=105$ _cong_billsanddocid=f:hj92enr.txt. pdf

Arizona v. California, 373 U.S. 546, U.S. Supreme Court 1963.

Arizona v. California, 547 U.S. 1, U.S. Supreme Court 2006.

Badr, A. W., A. Wachob, and J. A. Gellici, 2004. South Carolina Water Plan. Columbia, SC: South Carolina Department of Natural Resources: Land, Water, and Conservation Division.

Burke, B., 2004. Association of American Law Schools conference: Transcript of the section on natural resources in Atlanta, Georgia, January 5, 2004. Georgia State University Law Review, 21(2), 245-304.

Cary, N., 2013. South Carolina, Georgia leaders hope to avoid crisis, courts, to find Savannah River solutions. Retrieved from http://www.greenvilleonline.com/ article/20130919/NEWS07/309190010/South-CarolinaGeorgia-leaders-hope-avoid-crisis-courts-find-SavannahRiver-solutions

Catawba-Wateree Basin Advisory Commission. (n.d.). Retrieved from http://portal.ncdenr.org/web/wq/riverbasin-avdisory-commission/catawbarbac

Colorado River Governance Initiative, 2010. Rethinking the future of the Colorado River (draft interim report). Boulder, CO: Author.
Colorado v. Kansas et al., 320 U.S. 383 (U.S. Supreme Court 1943).

Cook, B. I., T. R. Ault, and J. E. Smerdon, 2015.

Unprecedented 21st century drought risk in the American Southwest and Central Plains. Sci. Adv., 1(e1400082), 1-7. Delaware River Basin Compact, 87-328, 1961.

Dellapenna, J. W., 2005. Interstate struggles over rivers: The southeastern states and the struggle over the 'Hooch'. New York University Law Journal, 12, 828-900.

Dellapenna, J. W., 2006. The law, interstate compacts, and the southeastern water compact. In J. L. Jordan, and A. T. Wolf (Eds.), Interstate Water Allocation in Alabama, Florida, and Georgia: New Issues, New Methods, New Models (1st ed., pp. 51-77). Gainsville: University Press of Florida.

Dyckman, C. S., 2008. Another "Case of the Century?": Comparing the legacy and potential implications of Arizona v. California in the South Carolina v. North Carolina proceedings. Proceedings of the 2008 South Carolina Water Resources Conference, Charleston, SC.

Florestano, P. S. (1994). Past and present utilization of interstate compacts in the United States. Publius, 24(4), 13-25.

Frankfurter, F. and J. M. Landis, 1925. The compact clause of the constitution. A study in interstate adjustments. Yale Law Journal, 34(7), 685-758.

Georgia Environmental Protection Division, 2008. Georgia Comprehensive State-wide Water Management Plan. Atlanta, GA: Author.

Georgia Environmental Protection Division, and SC Department of Health and Environmental Control. (n.d.). Savannah River Basin Partnership. Retrieved from http:// savannahriverbasin.org/

Gortner, H. F., K. L. Nichols and C. Ball, 2007. Organization theory: A public and non-profit perspective (3rd ed.). Belmont, CA: Wadsworth.

Governor's Water Law Review Committee, 2004. Water Law Report. Columbia, SC: Author.

Hardin, G., 1968. The tragedy of the commons. Science, 162(3859), 1243-1248.

Hayton, R. D., and A. E. Utton, 1989. Transboundary groundwaters: The Bellagio Draft Treaty. Natural Resources Journal, 29(Summer), 668-722.

Holman, J. B., 2008. The advent of modified riparianism in South Carolina. Southeastern Environmental Law Journal, 16.2(Spring), 291-357.

Kearney, R. C., and J. J. Stucker, 1985. Interstate compacts and the management of low level radioactive wastes. Public Administration Review, 45(1), 210-220.

League of Women Voters of South Carolina Water Resources Study Committee, 2011. Quenching our state's thirst: A report on the water resources of South Carolina. Columbia, SC: League of Women Voters of South Carolina.

Lepawsky, A., 1950. Water resources and American federalism. American Political Science Review, 44(3), 631-649.

Mandarano, L. A., J. P. Featherstone, and K. Paulsen, 2008. Institutions for interstate water resources management. Journal of the American Water Resources Association, 44(1), 136-147. 
McClurg, S., 1997. The Colorado Compact: 75 years later. Western Water, September/October, 5-17.

Mulroy, P., 2008. Beyond the divisions: A compact that unites. Journal of Land Resources and Environmental Law, 28(1), 105-117.

Muys, J. C., 1995. Approaches and considerations for allocation of interstate waters. In K. M. Carr, and J. D. Crammond (Eds.), Water law: Trends, policies, and practice (pp. 311-319) American Bar Association.

Muys, J. C., G. W. Sherk, and M. C. O'Leary, 2007. Utton Transboundary Resource Center model interstate water compact. Natural Resources Journal, 47(1), 17-115.

Nagourney, A., 2015. California imposes first mandatory water restrictions to deal with drought. Retrieved from http://www.nytimes.com/2015/04/02/us/californiaimposes-first-ever-water-restrictions-to-deal-withdrought.html? src $=\mathrm{xps}$

Nebraska v. Wyoming, 325 U.S. 589, U.S. Supreme Court 1945.

North Carolina General Assembly. (n.d.). River Basins Advisory Commissions. Retrieved from http://www. ncleg.net/gascripts/statutes/statutelookup.pl?statute $=77$

Ostrom, E., 1990. Governing the commons: The evolution of institutions for collective action. Cambridge: Cambridge University Press.

Robison, J. A., and L. J. MacDonnell, 2014. Arizona v. California and the Colorado River Compact: Fifty years ago, fifty years ahead. Arizona Journal of Environmental Law and Policy, 4, 130-159.

Savannah River Basin Advisory Council. (n.d.). Savannah River Basin Advisory Council Top Issues. Retrieved from https://sites.google.com/site/savannahriverbac/home/ savannah-river-basin-issues

S.C. Savannah River Basin Advisory Council. (n.d.). Hot issues/Current activities. Retrieved from https://sites.google. $\mathrm{com} /$ site/savannahriverbac/current-studies-permitting Schlager, E., and T. Heikkila, 2009. Resolving water conflicts: A comparative analysis of interstate river compacts. Policy Studies Journal, 37(3), 367-392.

Sherk, G. W., 2005. The management of interstate water conflicts in the twenty-first century: Is it time to call uncle? New York University Environmental Law Journal, 12(3), 764-827.

South Carolina General Assembly, 2004. South Carolina Code of Laws, Title 44- Health, Chapter 59, River Basins Advisory Commissions. Retrieved from http://www. scstatehouse.gov/code/t44c059.php

South Carolina v. North Carolina settlement agreement, 2010. Retrieved from http://portal.ncdenr.org/web/wq/ river-basin-avdisory-commission/catawbarbac

Stephenson, D. S., 2000. The tri-state compact: Falling waters and fading opportunities. Journal of Land Use and Environmental Law, 16(1), 83-109.

U.S. Census Bureau, Population Division, 2005. South Carolina community profiles: South Carolina 2030 population projections. Retrieved from http://www. sccommunityprofiles.org/census/sc_proj.php
U.S. Constitution, Article I. (n.d.). Retrieved from https:// www.law.cornell.edu/constitution/articlei\#section10

Wachob, A., A. D. Park, and J. R. Newcome, (Eds.), 2009. South Carolina state water assessment (2nd. ed.). Columbia: South Carolina Department of Natural Resources.

Wines, M., 2015. Mighty Rio Grande now a trickle under siege. Retrieved from http://www.nytimes. com/2015/04/13/us/mighty-rio-grande-now-a-trickleunder-siege.html? src $=$ xps

Zimmerman, J. F., 2012. Interstate water compacts: Intergovernmental efforts to manage America's water resources. Albany: State University of New York Press. 